\section{研究所紹介シリーズ 3}

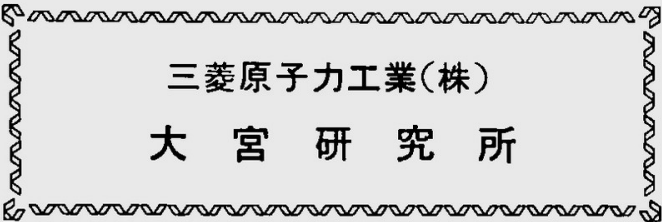

\section{I . 三美の原子力事業体制}

\section{1. 序}

三菱原子力工業㑣は我が国最初の原子力専業会社と して1958年 4 月設立以来，PWR プラントの基本設計. 研究開発などソフトウェフ部門を担当し，我が国にお ける原子力技術の確立と普及に貢献してきた。

当社が今日まで手掛けた PWR プラントは営業運転 中のbの14基, 設計ないし建設中のもの 7 基, その他 原子力第 1 船「むつ」用原子炉設備を設計, 製作した。ま た，原子然料については，上記 PWR プラント用初装 荷および取替燃料関係の業務を分担している。

一方，開発炉については動然事業団に協力して高速 実験炬「常陽」,新型転換炬原型炉「ふげん」の R\&D およ び設計·製作,ならびに高速増殖原型姖「むんじゅ」の設 計·製作・建設に取り組んでいる。さらに各炉型の然料 サイクルにも国家計画に協力しつつ技術開発を進めて いる。

2. 三美グルーブ内の業務分担

三菱原子力工業：原子カブラント・然料の

基本設計括よび研究開発

三菱重工業(㨆：原子カプラント・然料の全体

とりまとめ, 詳細設計, 機器製作および建設

三菱電機㑣： 電機品の設計·製作

三菱原子燃料侏：PWR 燃料の製造

その他,三菱金属㑣，三菱商事㑣，三菱化成工業㑣

等の各社はそれぞれ分担業務を遂行してい る。

3. 三菱原子力工菜林の主な業雅内容

(1) 原子カプラントの設計(舶用炉を含む). 研究開発

(2) 原子燃料の設計・研究開発

(3) 原子力関連機器設備の設計·研究開発

\section{II. 三菱原子力工業侏大宮研究所}

\section{1. 䋎 幾}

当研究所の歴史は1958年 8 月，現在地に然料部を設
置,核然料の研究を手掛けたことから始まる。その後, 分離·統合等幾多の変遷を経てきたが，現在の組織は， 所長の下に管理部, 研究第一部, 同第二部が圆かれてい る。

研究第一部： 原子力に関する化学,扰よび核然料 サイクルの研究開発を担当。

研究第二部： PWR 然料の多面的開発研究およひ FBR然料の基本設計・試作開発研究を担当。

放射線管理チーム：原子力の R\&D,プラント運 転, 原子炉解体など, 現在注目されている分野の放射線 管理業務を担当。

な扣当研究所の特徵の一つは，クルーブ内では最大 の核然料評価施設扰よび放射性同位元素の研究施設を 保有し，これらを駆使してクループ各社，特に三菱重 工業侏の原子カプラント部門である神戸造船所・高砂 研究所等と密接な連携を保ちつつR\&Dを推進してい る点である。



写仝 1 大宮研究所本館

2. 主要な研究テーマ

（1）軽水炉

（1）燃料開発： 負荷追従運転や高然焼度運転の達 成，APWR 大型炉心，高転換型炉心の開発などを目指 すとともに, 然料の高珄能化の要請に応えるぺく $\mathrm{UO}_{2}$ ペレットの改良実験を初め被覆管，支持格子などの然 料部品户燃料集合体について材料技術実験, 機械試験,

流水試験(写真 2)等を実施している。

また LOCA 等, 事故時然料挙動の把挃実験も実施し ている。さらに, 燃料炉中挙動解析手法や燃料耐兆解 析手法なと，設計解析手法の開発にも力を入れてい る。このほか, 現行然料や新規開発燃料の性能確認の ため，国内外の各種原子妒を用いた照射試験を多面的 に実施している。

(2) 1 次系化学：この分野では環境保全,被曝低 减化, プラントの信頼性向上, 省力化, コスト低減等, 優 れた PWR プラントの実現を目指した基礎研究を行な っている。 


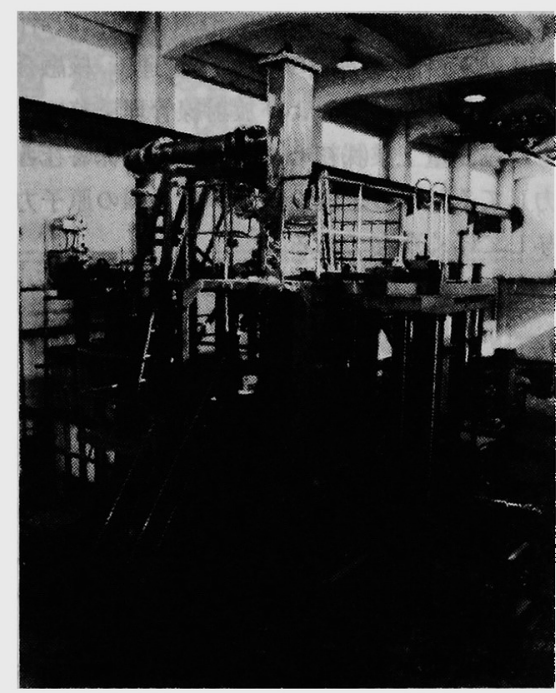

写真 2 燃料集合体水流動試験装置

主要な研究項目としては

(1) 材料の腐食とその腐食生成物(主として放射 性クラッド)の挙動ならびにこれらの低减化 を目指した水化学管理法の改良研究（写真 3 )

(2) 水質管理技術の開発

(3) プラント安全性(ソースターム)や燃料健全 性(㜣料リーク)に対する評価

(4) 廃棄物処理・処分技術の開発研究

(5) 除染ならびに廃炉技術の開発

等であり，放射性同位元素をフルに，かつ効果的に活 用した研究を行なっている。

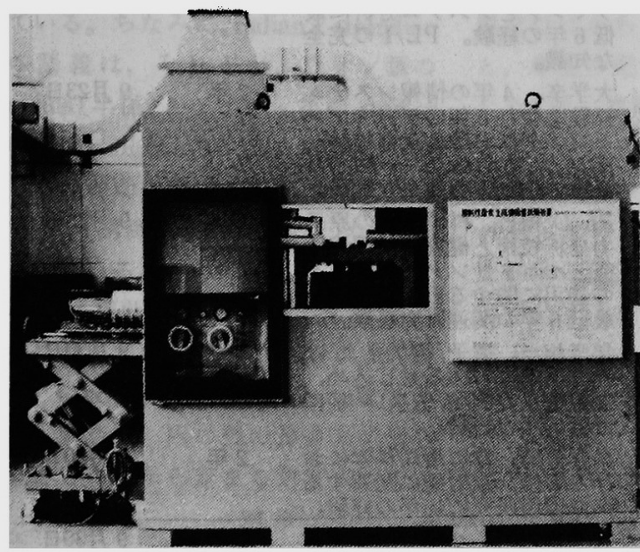

写真 3 ホット高温高圧水試験ループ

(2) 開発炉

(1) FBR 燃料の開発： プラント設計や妒心設計と の整合性を重視した燃料の構造設計, 熱流力解析, 設計
手法の開発や試作などを進めている。設計手法開発ま では燃料要素集合体の炬中挙動, 燃料集合体内伝熱流 動, 炬心構成要素の群振動等に関し，FBRのコストダ ウンを目指して新しい手法を取り入れたソフト開発を 実施している。

(2) 放射性 $\mathrm{Na}$ 技術の開発： FBR では放射能放 出低減, 被曝低減, $\mathrm{Na}$ 管理等の観点か、ら, $\mathrm{Na}$ の純化, 除 染, 廃 $\mathrm{Na}$ の処理, $\mathrm{Na}$ 分析等の技術開発を実施してい る。

(3) 核融合ブランケット材料の開発：酸化リチウ ム,アルミン酸りチウムなどセラミック系ブランケッ 卜材料の試作および各種物性測定, 基礎的評価研究を 実施している。

（3）燃料サイクルの研究開発

（1）遠心法ウラン濃縮技術の開発：動燃事業団中 心の国家計画に協力して分離理論，システム設計用計 算コードの開発および単体機器の基礎研究を実施し た。動燃事業団が推進中のFBR然料リサイクル試験施 設などの設計には，三菱グループの一員として安全設 計関係を担当している。

(2) 廃棄物処理関係：再処理扣よびU濃縮を初め PWR の廃棄物処理・処分を含めて, Pd 合金膜による 廃ガスの分離回収, 逆浸透膜による液体廃棄物処理 お。 よびガラス固化,プラスチック固化などのシステマテ ヘックな技術開発を行なっている。

(4) 放射線管理

（1）所内管理： 許認可業務, 放射性物質の管理, 施 設放射線管理および個人被曝管理(写真 4)

(2) PWR プラントの放射線 管理 : 美浜 1 号機以 来, 試運転, 定検作業等に参画し, 現在も管理手 法の改良に努力している。

（3）保健物理分野を主体とした放射線管理技術の開 発：ALARA の精神に基づ原子力施設の被曝 低减化対策の提案, 同評価手法の開発, 被曝線量測 定手法の開発, 核物質防護, 計量管理技術の改良等

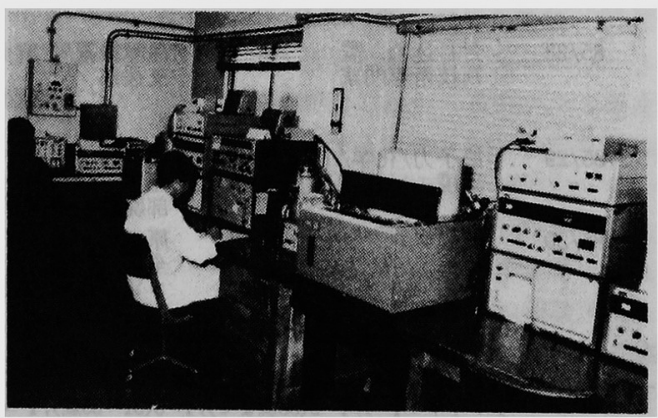

写真 4 放射線測定室 
を行なっており，成果は関係者上り注目されてい る。

$$
\text { II.むすび }
$$

大宮研究所は当社の設計部門を支援する役割を担ら とともに，原子力の最先端技術，いわゆるシーズの開 発を通じてグルーブ内の全原子力部門の中核的役割を 果している。
特に，PWR 燃料の高性能化，FBR 然料の設計開発， 然料サイクルの諸問題, PWR の安全運転, 核融合炉ブ ランケット材料の開発扰よび放射線管理業務には，今 後とむ，三菱望工業㑣初めグループ内関係各社と密接 に势力してそれらの玉成を図り，我が国の原子力開発 に寄与してゆく所存である。

(三菱原子力工業儌大宮研究所宮崎由朗) (1985年7月 4 日受理)
IAEA 職員空席情報（1985.7.30. 現在） (VN=Vacancy Notice)

Vol. 27, No.7(p. 662)kつついて, IAEA 事務局職貝

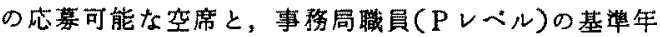

龄湢, 必要経鋥年数，学歴別等を㕲知らせします。 萦の詳細については，下記へお問合せ下さい。

○科学技術庁原子力局調查国際協力課

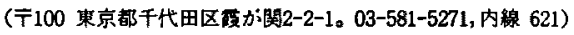
○外務省国際機関人事センターー(03-580-3311, 内線 2840)

\begin{tabular}{|c|c|c|c|c|c|c|}
\hline ポスト番号 & ポスト & グレイド & 所 鷿 & 資格·程駘 & 任期 & IAEA稚切日 \\
\hline $85 / 22$ & 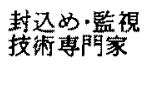 & $P-4$ & $\begin{array}{l}\text { 保障措置局 開発技徒 } \\
\text { 支援部 }\end{array}$ & 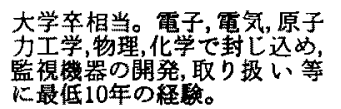 & 2 年 & 9 月16日 \\
\hline $85 / 24$ & 核然料専門家 & $P-4$ & $\begin{array}{l}\text { 原子力エネルギー・安 } \\
\text { 全局核然料+イクル } \\
\text { 部核物聶·燃料サイク } \\
\text { ル技兾課 }\end{array}$ & 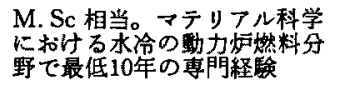 & 2 年 & 9 月16日 \\
\hline $85 / 25$ & 統計学者 & $P-4$ & $\begin{array}{l}\text { 保竪措置局 查審言価 } \\
\text { 部デー夕評価課 }\end{array}$ & 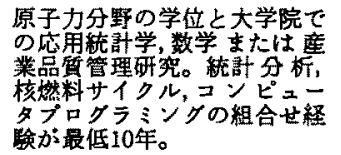 & 2 年 & 9 月 16 日 \\
\hline $85 / 26$ & $\begin{array}{l}\text { システムアナ } \\
\text { リスト }\end{array}$ & $P-3$ & 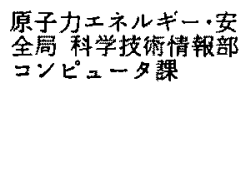 & 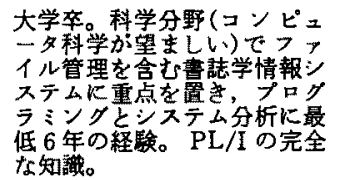 & 2 年 & 9 月 16 日 \\
\hline $85 / 23$ & $\begin{array}{l}\text { システムアナ } \\
\text { リスト }\end{array}$ & $P-3$ & 同上 & 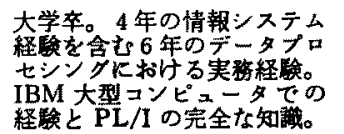 & 2 年 & 9月23日 \\
\hline $85 / 27$ & $\begin{array}{l}\text { 原子力分析科 } \\
\text { 学者 }\end{array}$ & $P-3$ & $\begin{array}{l}\text { 研究·アイソトープ局 } \\
\text { 生物科学部 }\end{array}$ & 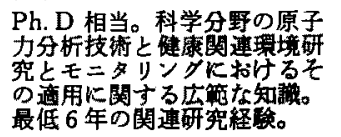 & 2 年 & 9 月23日 \\
\hline $85 / 28$ & $\begin{array}{l}\text { 封じ込め, 臨 } \\
\text { 視技衔尃門家 }\end{array}$ & $P-4$ & $\begin{array}{l}\text { 保障措置局 開発技術 } \\
\text { 支援 }\end{array}$ & 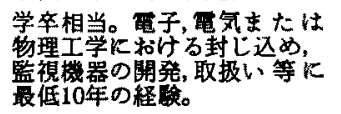 & 2 年 & 9 月30日 \\
\hline $85 / 29$ & $\begin{array}{l}\text { 原子力/化学/ } \\
\text { 隚境エンシ } \\
7\end{array}$ & $P-5$ & 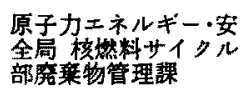 & 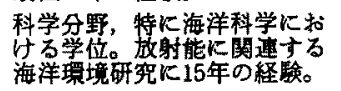 & 2 年 & 9 月30日 \\
\hline $85 / 30$ & 開発プロタラ & $\mathbf{P}-2$ &  & 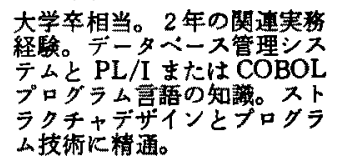 & 2 年 & 9 月 30 日 \\
\hline
\end{tabular}

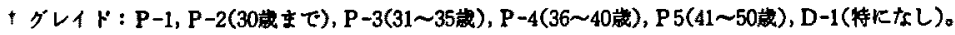

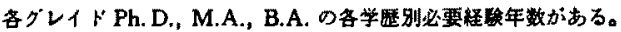

